\title{
Preliminary Analysis of Some Waters From the Confined Aquifers Underlying the Hanford Site
}

R. A. Deju

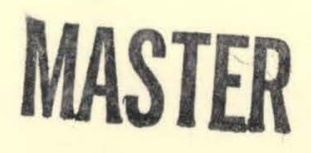

September 1978

Prepared for the United States

Department of Energy

Under Contract EY-77-C-06-1030

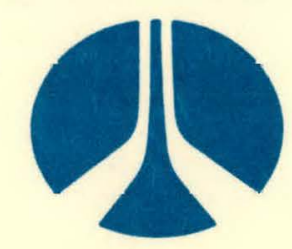

Rockwell International

Rockwell Hanford Operations

Energy Systems Group

Richland, WA 99352 


\section{DISCLAIMER}

This report was prepared as an account of work sponsored by an agency of the United States Government. Neither the United States Government nor any agency Thereof, nor any of their employees, makes any warranty, express or implied, or assumes any legal liability or responsibility for the accuracy, completeness, or usefulness of any information, apparatus, product, or process disclosed, or represents that its use would not infringe privately owned rights. Reference herein to any specific commercial product, process, or service by trade name, trademark, manufacturer, or otherwise does not necessarily constitute or imply its endorsement, recommendation, or favoring by the United States Government or any agency thereof. The views and opinions of authors expressed herein do not necessarily state or reflect those of the United States Government or any agency thereof. 


\section{DISCLAIMER}

Portions of this document may be illegible in electronic image products. Images are produced from the best available original document. 


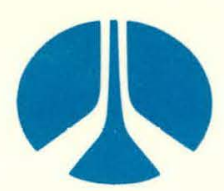

Rockwell International

Rockwell Hanford Operations

Energy Systems Group

Richland, WA 99352

PREPARED FOR THE UNITED STATES DEPARTMENT OF ENERGY

UNDER CONTRACT EY-77-C-06-1030

\section{PRELIMINARY REPORT}

This Report contains informatioun uf a pielinniıary natuıe. It is subject to revision or correctıon and therefore does not represent a final heport. Il was prepared primarily for internal use within The Rockwell Hanford Operations. Any expressed views and opinions are those of the Author and not necessarily of the Company.

\section{NOTICE}

This Report was prepared as an account of work sponsored by the United States Government. Neither the United States nor the United States Department of Energy, nor any of their Employees, nor any of their Contractors, Subcontractors, or their Employees, makes any warranty, express or implied, or assumes any legal liability or responsibility for the accuracy, completenees, or usofulness of any information, apparatus, product or process disclused, ur represents that its use would not infringe privately owned rights. 


\author{
R. A. Deju \\ Program Director \\ Basalt Waste Isolation Program
}

September 1978

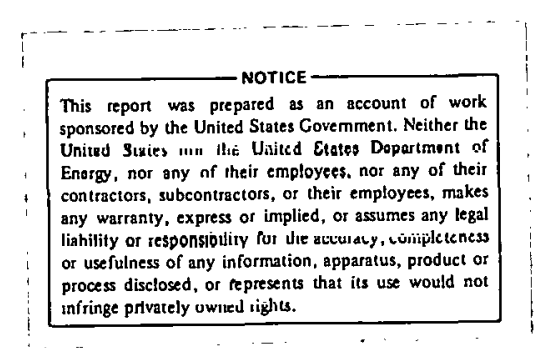

DISTRIBUTION OF THIS DOCUBHET IS UNLIMITED

Rockwell International

Rockwell Hanford Operations

Energy Systems Group

Richland, Washington 99352 


\section{A B STRACT}

This report presents results of analyses available at this point in time from waters from some wells sampled in or near the Hanford Site. The analyses of these wells were done for various purposes and are consolidated to help us define the nature of the waters found within the Colrombia Plateau basaltic sequence. Results of the analyses show the waters from the unconfined aquifers undertying the Hanford Site are characterized by a high calcium-magnesium content. These waters can be described as calcium-magnesium-bicarbonate-type. Waters from deeper basaltic confined aquifers are primarily of the sodium bicarbonate type. Two waters sampled from the Grande Ronde Formation from Rattlesnake Hills Exploratory. Well Number 1 are slightly different and can be described as sodium-calcium-bicarbonate-sulfate-chloride-type. Age-dating results for these water samples lead to the conclusions that waters from the confined aquifers were entrapped 15,000 to 23,000 years ago. 
TABLE OF CONTENTS

Page

SUMMARY

4

INTRODUCTION

SAMPLING

ANALYSES

10

RESULTS

10

INTERPRETATION

10

REFERENCES

20

DISTRIBUTION

LIST OF FIGURES

FIGURE 1 STRATIGRAPHY OF THE PASCO BASIN 5

FIGURE 2 HANFORD AREA MAP SHOWING LOCATION OF WELLS SAMPLED

FIGURE 3 MAJOR CONSTITUENTS IN DB-1 (DUPLICATE SAMPLES) WATER FROM THE MABTON MEMBER

FIGURE 4 MAJOR CONSTITUENTS IN DB-2 (DUPLICATE SAMPLES) WATER FROM THE MABTON MEMBER

FIGURE 5 MAJOR CONSTITUENTS IN DB-7 (DUPLICATE SAMPLES) WATER FROM THE MABTON MEMBER

FIGURE 6 MAJOR CONSTITUENTS IN RSH-1 (DUPLICATE SAMPLES) WATER FROM THE GRANDE RONDE FORMATION

\section{LIST OF TABLES}

TABLE I AVERAGE COMPOSITION OF WATERS FROM AQUIFERS UNDERLYING THE HANFORD RESERVATION

TABLE II RESULTS OF ANALYSIS OF THE INTERVAL 540-620FOOT DEPTH OF ARH-DC-1 (UPPER CONFINED AQUIFER) DURING CONSTRUCTION OF THE WELL

TABLE III MAJOR CONSTITUENTS: ANALYTICAL RESULTS

TABLE IV TRACE CONSTITUENTS: ANALYTICAL RESULTS

TÁBLE V $C^{14}$ AND $0^{18}$ ANALYSES

TABLE VI RESULTS OF ${ }^{3}$ H ANALYSES 


\section{SUMMARY}

This report presents results of analyses available at this point in time from waters from some wells sampled in or near the Hanford Site. The analyses of these wells were done for various purposes and are consolidated to help us define the nature of the waters found within the Columbia Plateau basaltic sequence. Results of the analyses show the waters from the unconfined aquifers underlying the Hanford Site are characterized by a high calcium-magnesium content. These waters can be described as calciummagnesium-bicarbonate-type. Waters from deeper basaltic confined aquifars are primarily of the sodium bicarbonate type. Two waters sampled from the Grande Ronde Formation from Ratt.lesnake Hills Exploratory Well Number 1 (RSH-1) are slighly different and can be described as sodium-calciumbicarbonate-sulfate-chloride-type. Age-dating results for these water samples lead to the conclusions that waters from the confined aquifers were entrapped 15,000 to 23,000 years ago.

\section{INTRODUCTION}

The geology and hydrology of the Hanford Site have been extensively studied since nuclear operations were started over 30 years ago. Numerous papers and reports detail salient features of the aquifers underlying the Hanford area. $(1,2,3)$ In addition, the stratigraphy of the underlying strata has been summarized recently ${ }^{(4)}$ as shown in Figure 1.

Complete chemical analyses are available for many wells penetrating the unconfined aquifer* underlying the Hanford Site. These analyses have been reported previously. $(1,2,3)$ A more limited number of analyses exist for the uppermost confined aquifers. $(1,2)_{\star \star}$ Table I depicts the typical composition of both the unconfined and uppermost confined aquifers. Table II shows results of analyses of one of the uppermost confined aquifers. Since

\footnotetext{
*Unconfined Aquifer

- A water table aquifer in the unconsolidated and semi-consolidated sediment overlying the basalts.

**Uppermost Confined Aquifer - Waters obtained from or stratigraphically above the Mabton Member (4) and strata between it and the uppermost surface of the Columbia River basalts.
} 


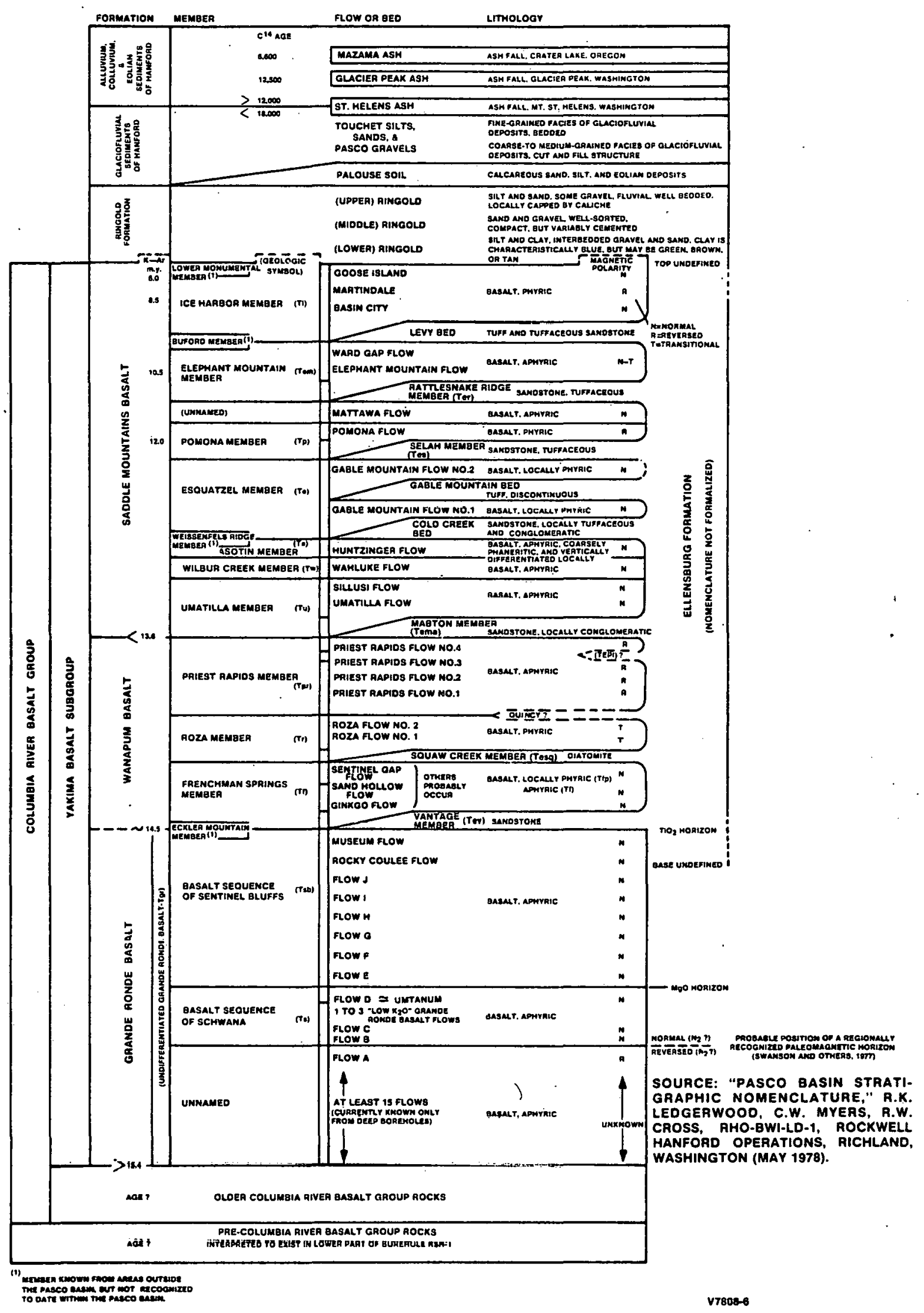

FIGURE I 


\section{TABLE I}

\section{AVERAGE COMPOSITION OF WATERS FROM AQUIFERS UNDERLYING THE HANFORD RESERVATION}

(Numbers in parentheses denote the range of values found.)

CONSTITUENTS
Sodium (mg/liter)
Calcium (mg/liter)
Magnesium (mg/liter)
Chloride (mg/liter)
Sulfate (mg/liter)
Bicarbonate (mg/liter)
Carbonate (mg/liter)
Hardness, tutal (my/liter)
Potassium (mg/liter)
pH

UNCONFINED AQUIFER

29
$(16-64)$

48

$(37-72)$

$(7.12$

13

$(3.1-24)$

58

$(20-150)$

172

$(115-315)$

0

(0)

170
$(110-220)$

6.8

$(4.6-13)$

8.0

$(7.5-8.1)$
UPPERMOST CONFINED AQUIFERS

40

(4.1-122)

15

$(7-18)$

7

$(0-11)$

16

(3.8-81)

9
$(0-29)$

152

(93-180)

3

$(0-15)$

66

(3-96)

9.0

$(4.5-17)$

8.0

$(7.2-8.7)$ 


\section{TABLE II}

RESULTS OF ANALYSIS OF THE INTERVAL 540-620-FOOT DEPTH OF ARH-DC-1. (UPPER CONFINED AQUIFER) DURING CONSTRUCTION OF THE WELL

CONSTITUENT
$\mathrm{SiO}_{2}$
$\mathrm{Na}$
$\mathrm{K}$
$\mathrm{Ca}$
$\mathrm{Mg}$
$\mathrm{Fe}$
$\mathrm{HCO}_{3}$
$\mathrm{CO}_{3}$
$\mathrm{SO}_{4}$
$\mathrm{Cl}$
$\mathrm{F}$
$\mathrm{NO}_{3}$
$\mathrm{~B}^{\mathrm{T} . \mathrm{D} . \mathrm{S} .}$
$\mathrm{Conductivity}$
$\mathrm{pH}$

\begin{tabular}{|c|c|}
\hline AMOUNT & QUANTITY \\
\hline 46 & mg/1iter \\
\hline 79 & $\mathrm{mg} / \mathrm{liter}$ \\
\hline 7.8 & $\mathrm{mg} / 1$ iter \\
\hline 2.1 & mg/liter \\
\hline 0.3 & $\mathrm{mg} / 1$ iter \\
\hline 0.10 & mg/liter \\
\hline 199 & $\mathrm{mg} / \mathrm{liter}$ as $\mathrm{CaCO}_{3}$ \\
\hline 10 & $\mathrm{mg} /$ liter as $\mathrm{CaCO}_{3}$ \\
\hline 0 & mg/liter \\
\hline 4.2 & $\mathrm{mg} / \mathrm{liter}$ \\
\hline 1.0 & $\mathrm{mg} / \mathrm{liter}$ \\
\hline 0.1 & mg/liter \\
\hline 0.06 & mg/liter \\
\hline 250 & $\mathrm{mg} / 1 \mathrm{iter}$ \\
\hline 344 & micromhos $/ \mathrm{cm}$ at $25^{\circ} \mathrm{C}$. \\
\hline 8.46 & - \\
\hline
\end{tabular}


this sample was taken from an upper confined aquifer at the interval 540620 feet during construction of Well ARH-DC-1, results should reflect a representative sample uncontaminated from any lower waters. Representative samples from the Vantage Sandstone Member and below have been heretofore nonexistent.

This report summarizes results of analyses conducted during the past two years in some wells within or near the Hanford Site. Sampled intervals range from the uppermost confined aquifers to horizons nearly 3,000 feet below the land surface. These investigations were not totally part of the Basalt Waste Isolation Program.

\section{SAMPLING}

A number of wells (DB-1, DB-2, DB-4, DB-7, DDH-3, 699-53-103, and 699-52-52) were sampled by Battelle, Pacific Northwest Laboratories for the Atlantic Richfield Hanford Company during the month of August 1976. Complete chemical analyses were obtained for Wells DB-1, DB-2, DB-7, and DDH-3. Carbon- 14 age dates were determined for all wells, and $0^{18} / 0^{16}$ ratios were measured for all except Well DB-4. Tritium-3 analyses were obtained for DB-1, DB-2, DB-7, DDH-3, and 699-53-103. In addition, RSH-1 was sampled in May 1977 by Atlantic Richfield Hanford Company and a complete chemical analysis was obtained. No age-dating data are available for Well RSH-I. The locations of all wells sampled are shown in Figure 2.

All sampling was done by the Water and Land Resources Section of Battelle, Pacific Northwest Laboratories, except for Well RSH-1 which was sampled by Atlantic Richfield Hanford Company. Well DB-1 has a water level within a few meters of the ground surface. A conventional centrifugal pump was used to both flush the well and subsequently sample it. Well 69953-103 is artesian and a water sample was directly obtained. For all other wells sampled, the water levels in the wells were below the capabilities for a centrifugal pump and, therefore, an air lift method was employed. The method entails the use of a long sampling tube being lowered into the well and air pressure from an air compressor used as the driving force to bring the water to the surface. All wells were sampled until a reasonably clean sample was obtained. In the case of $\mathrm{DDH}-3$, diesel oil and drilling mud contamination was detected and could not be removed even after 


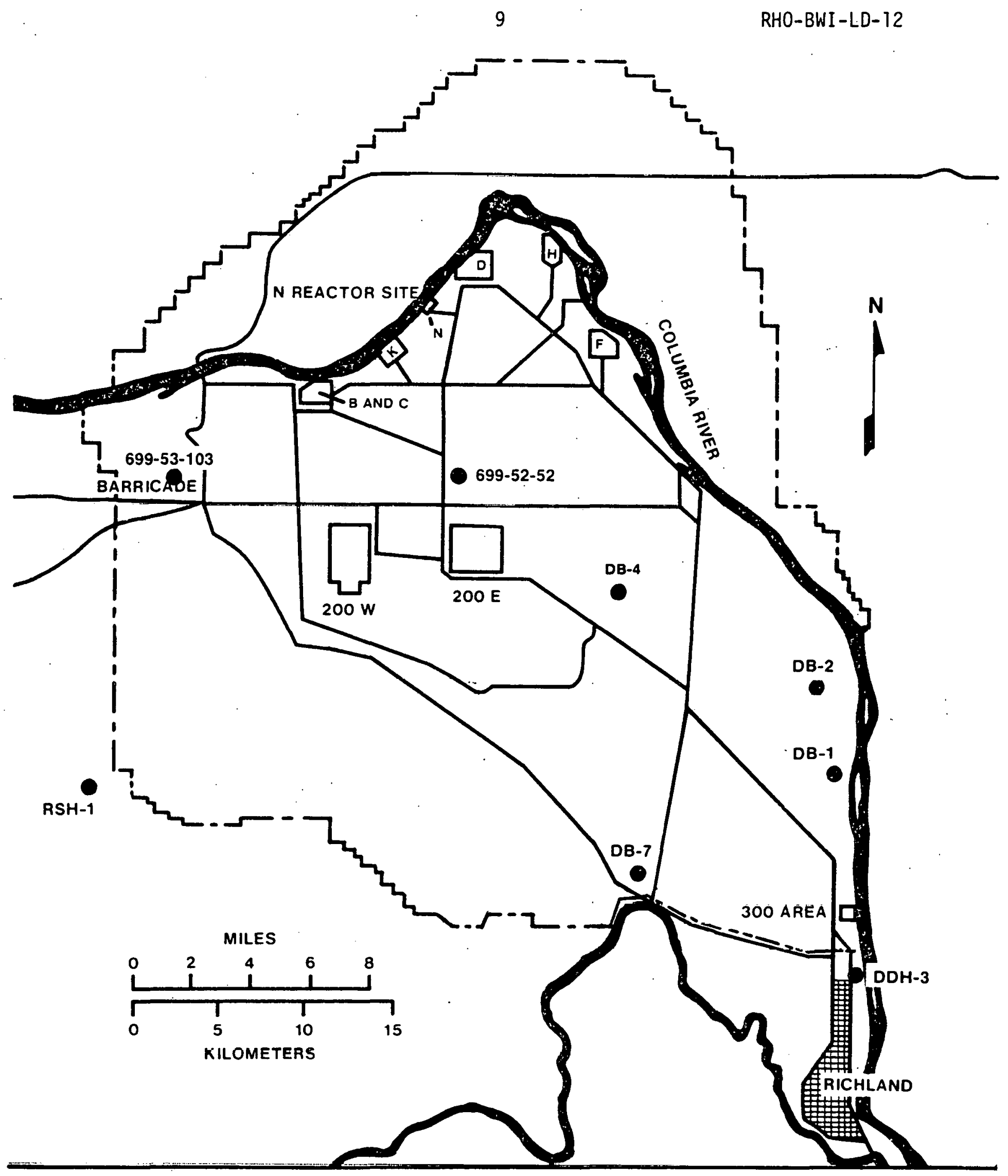

FIGURE 2

HANFORD AREA MAP SHOWING LOCATION OF WELLS SAMPLED 
extensive well clean out. Thus, $\mathrm{DDH}-3$ results are not representative of aquifer water and are simply given for completeness. For all other water samples obtained, the air lift method provided reproducible results. Well RSH-1 was sampled using a swab unit while testing for hydraulic conductivity in selected zones of the Grande Ronde Formation.

Duplicate samples for chemical composition were taken in all wells sampled and are reported in Tables III and IV.

\section{ANALYSES}

The chemical analyses were done by various laboratories under quality assurance procedures prepared jointly by Atlantic Richfield Hanford Company and Battelle, Pacific Northwest Laboratories. The project was under the direction of Dr. M. W. Grutzeck of Atlantic Richfield Hanford Company. The analytical work was divided as follows:

Major Constituents - United States Testing Company, Richland, Washington;

Trace Constituents - United States Testing Company, Richland, Washington; $c^{14}$ $0^{18} / 0^{16}$

- Washington State University, Pullman, Washington;

- Teledyne Isotopes, Westwood, New Jersey;

- University of Miami, Miami, Florida.

Laboratories were provided with blind samples. Duplicate samples were provided in all cases. Standard samples and blanks were also included in the suites to be analyzed.

\section{RESULTS}

Results of the analyses are reported in Tables III-VI. Table III shows the major constituents, while Table IV summarizes the trace constituents. Results of the $C^{14}$ and $0^{18}$ analysis are summarized in Table $V$. Table VI summarizes the results of the ${ }^{3} \mathrm{H}$ analyses.

\section{INTERPRETATION}

Waters from the unconfined aquifer underlying the Hanford Site are characterized by a high calcium and magnesium content (Table I). They can basically be described as calcium-magnesium-sulfate-bicarbonate waters. On 
TABLE II I

MAJOR CONSTITUENTS: ANALYTICAL RESULTS

(Sampling dates are in parentheses.)

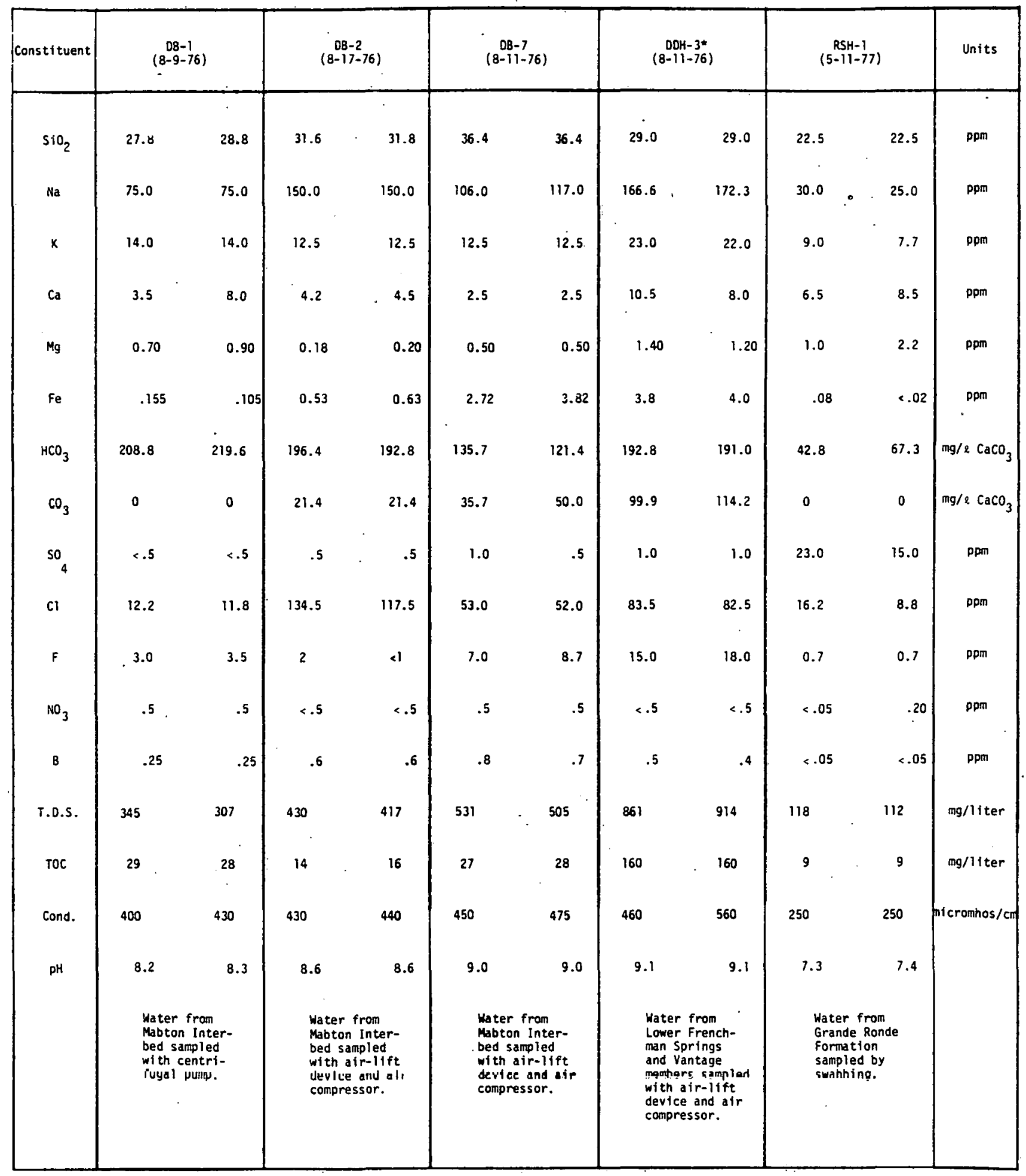


TABLE IV

TRACE CONSTITUENTS: ANALYTICAL RESULTS

(Sampling dates are in parentheses.)

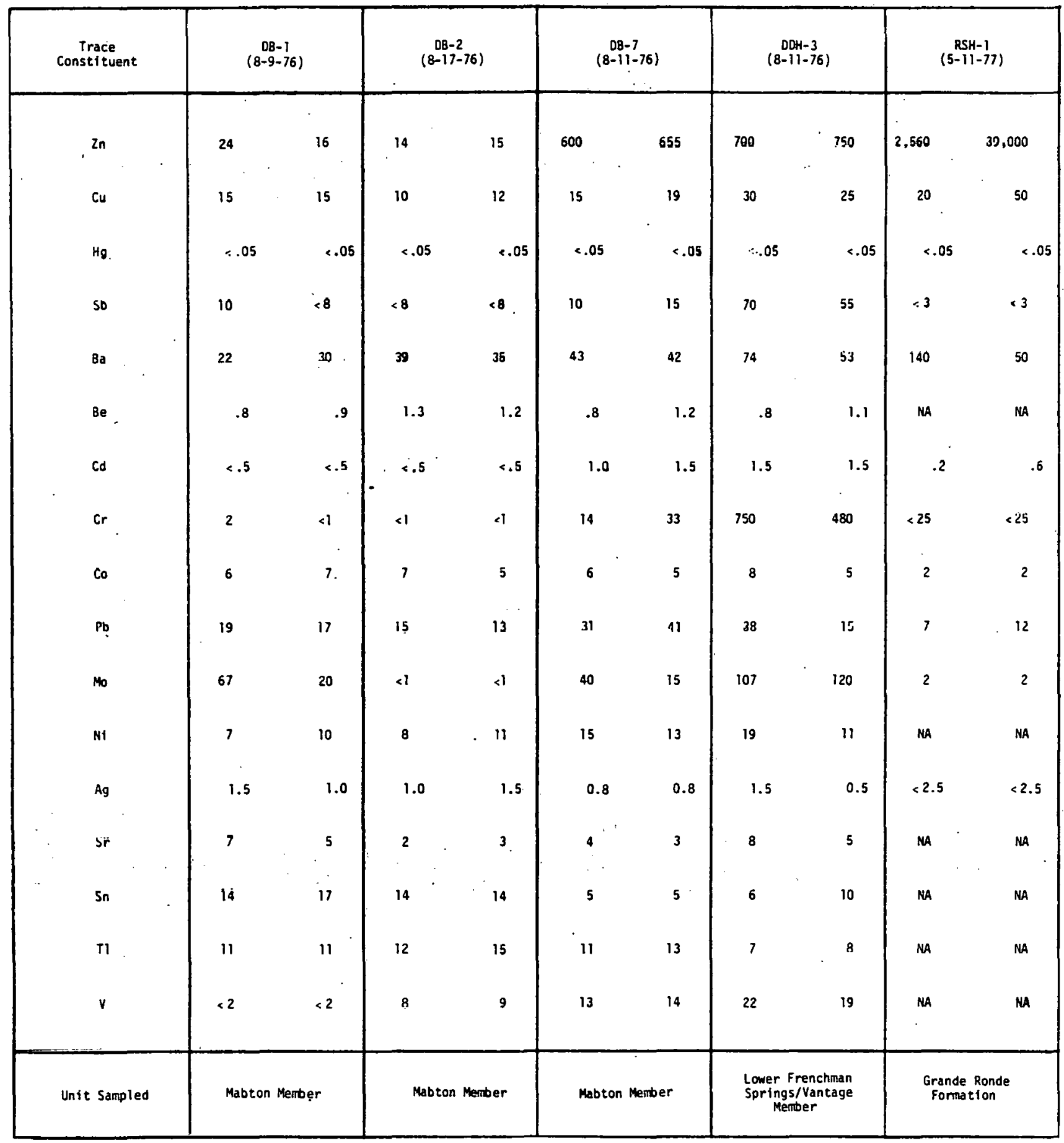




\section{TABLE V}

$C^{14}$ AND $0^{18}$ ANALYSES

WELL

$\mathrm{DB}-1$

$D B-2$

DB-7

$\mathrm{ODH}-3$

699-53-103

DB-4

$699-52-52$
$C^{14}$ AGES (YEARS) $\delta^{18} 0$ VERSUS SMOW*

$20,500 \pm 500 \quad-17.6$

$23,000 \pm 500$

$-17.6$

$-17.4$

$-15.2 \star \star$

$-18.0 * \star \star$

NAt

$15,400 \pm 250$

$-18.0+t$

*Standard Mean Ocean Water.

**Anomalously high metal ion content indicates sampling of stagnant water containing diesel oil and drilling mud.

$\star \star \star$ Mixed water from several confined aquifers.

NA= Not Analyzed

$\dagger$. Water from between the Mabton and Vantage.

++ Water from the uppermost confined aquifer. 


\section{TABLE VI}

RESULTS OF ${ }^{3}$ ANALYSES

$\begin{array}{ll}\frac{\text { WELL }}{\mathrm{DB}-1} & \frac{3 \mathrm{H} \text { RANGES }}{\text { Below Detection }} \\ \mathrm{DB}-2 & \text { Below Detection } \\ \mathrm{DB}-7 & \text { Below Detection } \\ \mathrm{DDH}-3 & 46-53 \mathrm{pCi} / \ell^{\star} \\ 699-53-103 & \text { Below Delecliun } \\ \begin{array}{l}\text { Upper Confined } \\ \text { Aquifers Range }\end{array} & 500-4,000 \mathrm{pCi} / \ell \\ \text { Unconfined Aquifer } & 10^{3} \mathrm{pCi} / \ell-3 \times 10^{6} \mathrm{pCi} / \ell \\ \text { Concentration Guide } & 3 \times 10^{6} \mathrm{pCi} / \ell \\ \text { USD0E Manual. Chapter } 0524 \\ \text { Level of Detection }\end{array}$

*Contaminated sample. 
the other hand, the waters in the uppermost confined aquifers are primarily sodium-bicarbonate (Table I).

Generally, waters from basaltic aquifers are characterized by high ratios of calcium to sodium and of magnesium to calcium, a relatively high silica content, and a relatively high fluoride content. ${ }^{(5)}$ The waters in the uppermost confined aquifers (Table I) and those values reported in Table III for the uppermost confined aquifer are atypical basalt waters and appear to be influenced by the sedimentary interbeds and not the basalt proper. The water from Well RSH-1, obtained from the Grande Ronde Formation, is slighly different and can be described as a sodiumcalcium-bicarbonate sulfate-chloride water; however, its composition is also atypical of basalt waters.

LaSala and Doty ${ }^{(6)}$ have examined numerous water analyses of Columbia Plateau basaltic aquifers. They concluded that the waters were typical of those found in sedimentary aquifers. The silica content of these waters indicates near-equilibrium with a silica phase having properties similar to those of chalcedony or cristobalite. The silica probably comes into solution from feldspars and other minerals, but at a concentration higher than that at which it would be in equilibrium with quartz. $(7,8)$ The solubility of quartz is particularly low and would account for only 5 to 15 parts per million $\mathrm{SiO}_{2}$ in the water. Other silicate minerals, however, have solubilities intermediate between quartz and amorphous silica (40 parts per million).

The major constituents of the waters obtained from Wells DB-1, DB-2, $\mathrm{DB}-7$, and $\mathrm{RSH}-1$ are depicted in semi-logarithmic diagrams in Figures 3 through 6 , respectively. The equilibrium $\mathrm{pH}$ with respect to $\mathrm{CaCO}_{3}$ of all these waters is higher than the actual $\mathrm{pH}$. The results from the analyses are also fairly close in the duplicate samples.

Application of the Palmer classification ${ }^{(9)}$ to the waters from DB-1, $\mathrm{DB}-2, \mathrm{DB}-7$, and $\mathrm{RSH}-1$ * shows that all the waters are Class I waters and, in the bulk of the samples, the primary alkalinity is dominant, indicating waters in contact with sedimentary strata. Well DB-7 shows also a high primary salinity, probably due to the basaltic influence on the water composition.

*Well DDH-3 water was not further studied, since the sample appeared to be contaminated. 


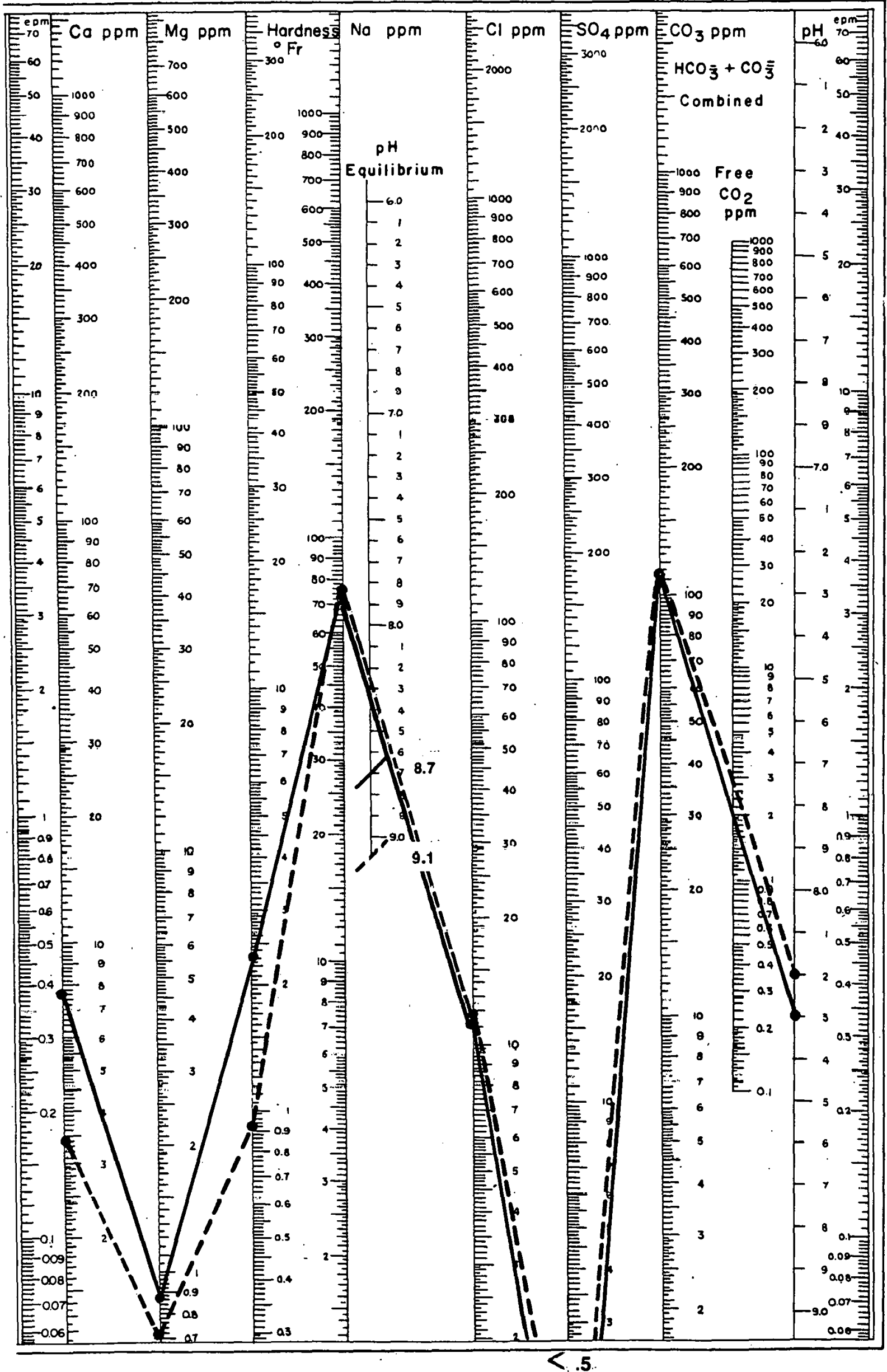




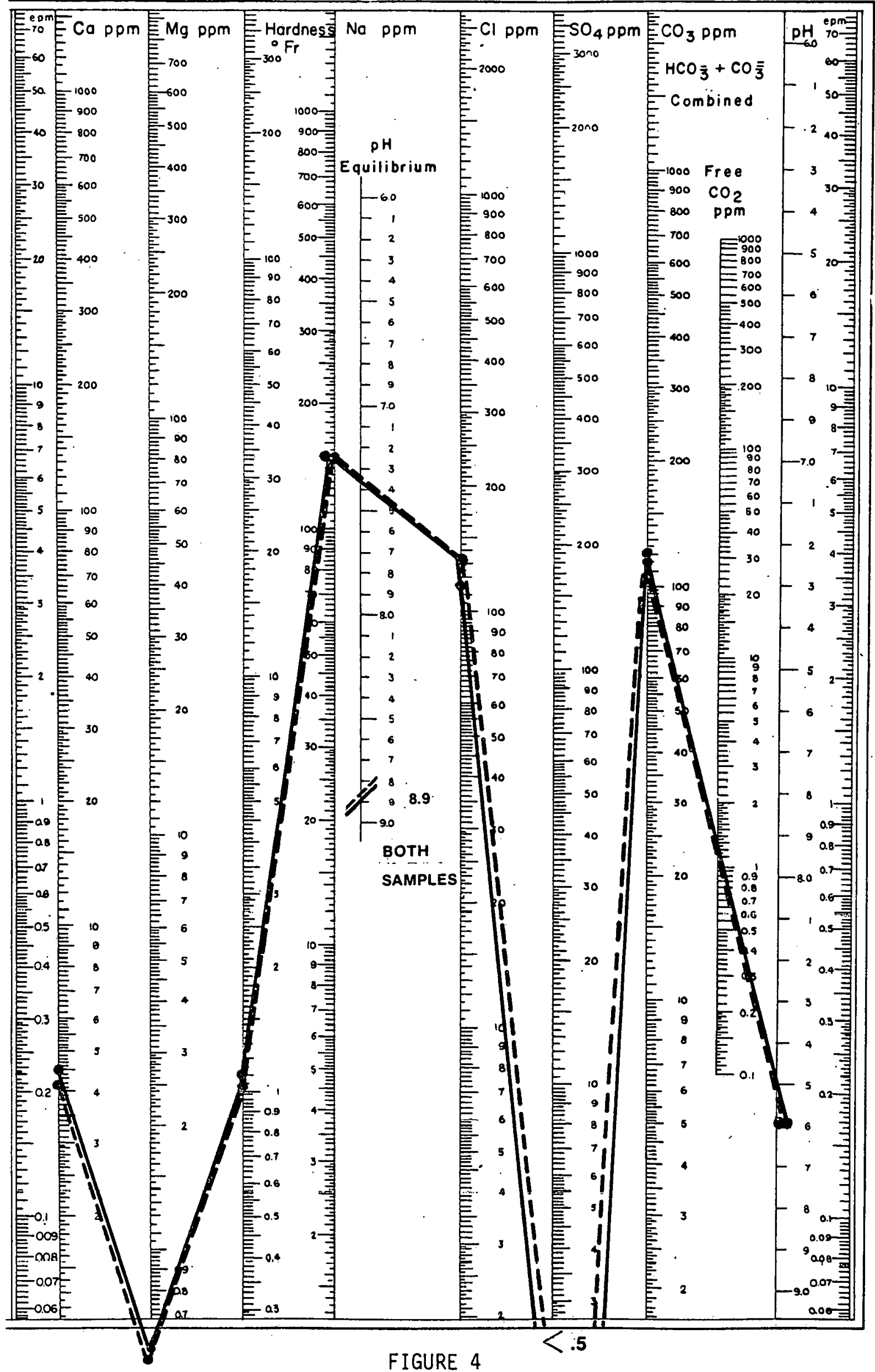




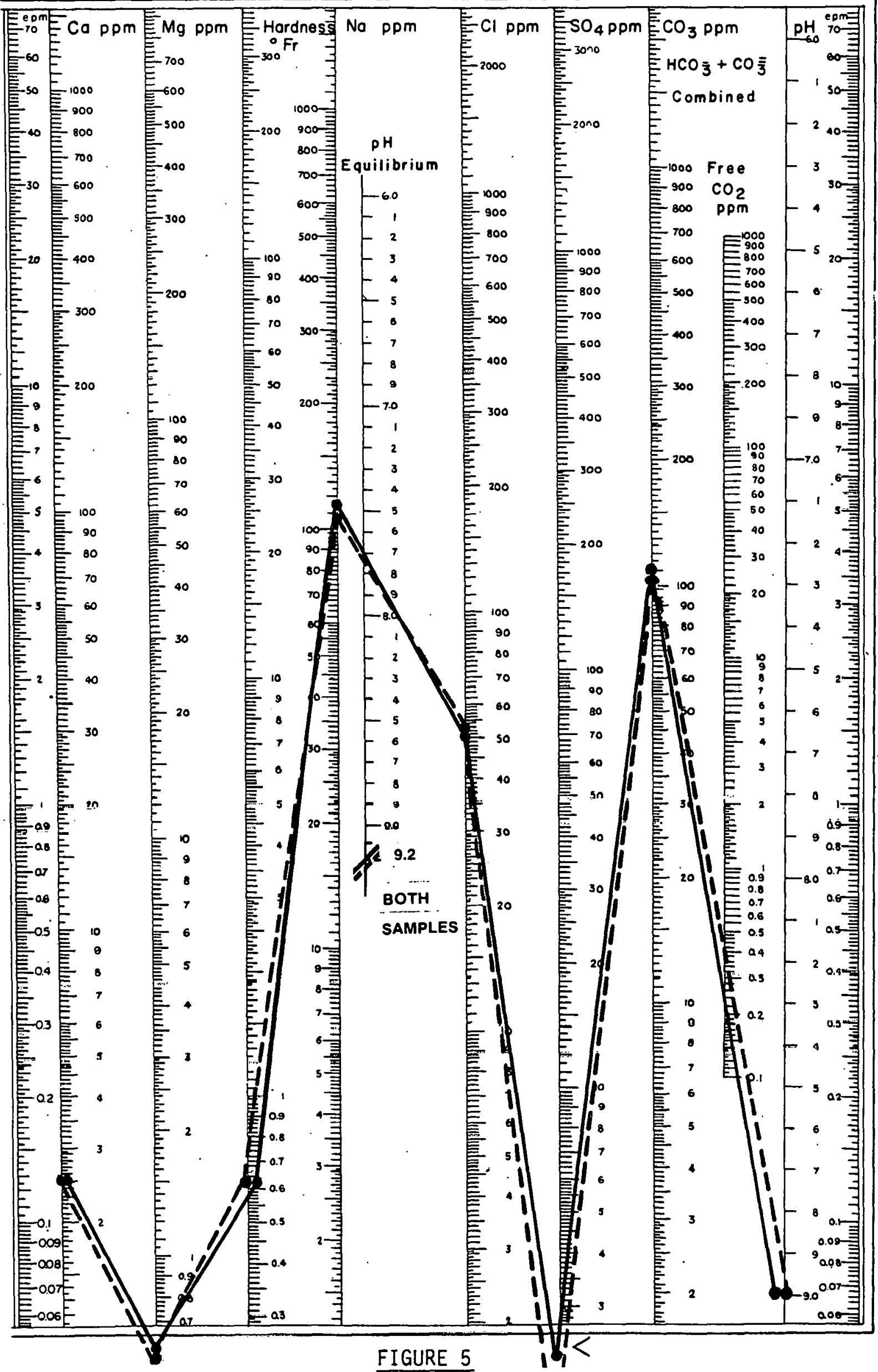




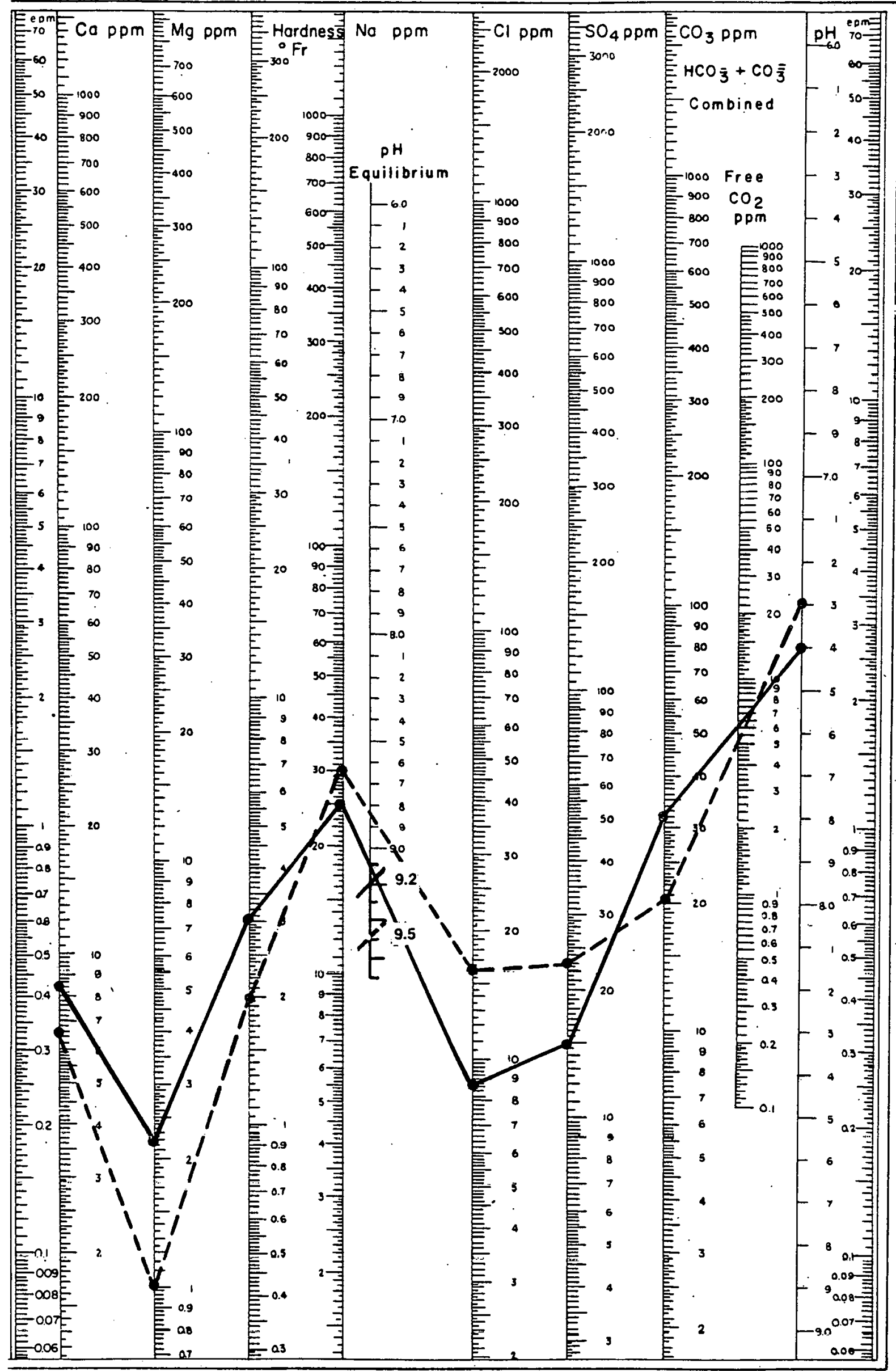


In the waters depicted in Figure 3 through 6 , sodium is the predominant cation present. These waters appear to be in equilibrium with a feldspar of about equal calcium and sodium content.

The cation-anion balances of the waters from DB-1, DB-2, DB-7, and RSH- I are within 0.8 to 14.8 percent, averaging 5.5 percent. In over 60 percent of the samples, the balance is within 2 percent.

The main trace constituents are $\mathrm{Zn}, \mathrm{Cu}, \mathrm{Ba}, \mathrm{Pb}$, and $\mathrm{Mo}$. Zinc is present in concentrations as high as 39 parts per million (RSH-1 sample; Table IV). Well water from DOH-3 shows anomalously high $\mathrm{Cr}$ and Mo. Potential sources of contamination in $\mathrm{DDH}-3$ are diesel fuel and molbydenum disulfide grease, which were probably used during drilling operations.

The U.S. Geological Survey ${ }^{(6)}$ analyzed the $C^{14}$ content of the bicarbonate dissolved in water from the uppermost confined aquifers in Well ARHDC- 1 within the Hanford Site. Their measured $C^{14}$ content was then adjusted for the dilution effects of carbonate mineral solution, using the $C^{13}$ value of bicarbonate. (10) They found an adjusted age of about 13,000 years before present. The same procedure was followed for the wells in Figure 2 whose dates are reported in Table $V$. Adjusted ages range from 15,400 to 23,000 years before present. Results for $\mathrm{DDH}-3$ denote some contamination.

The $\delta^{18} 0$ versus standard mean ocean water values reported in Table $V$ are representative of waters recharged during a glacial stage when a colder climate prevailed. Results for DDH-3 reflect some contamination.

Further, the ${ }^{3} \mathrm{H}$ results (Table VI) show very 1 now ${ }^{3} \mathrm{H}$ in the confined aquifer system sampled, probably due to lack of interconnection between these and aquifers closer to the land surface. The results for DDH-3 reflect some contamination.

\section{REFERENCES}

1. U. S. Energy Research and Development Administration, Final Environmental Statement, Waste Management Operations, Hanford Reservation, Richland, Washington, ERDA-1538, U. S. Energy Research and Development Administration, Washington, D. C. (December 1975).

2. Staff, Research and Engineering Division, Preliminary Feasibility Study on Storage of Radioactove Wastes in Columbia River Basalts, ARH-ST-137, Atlantic Richfield Hanford Company, Richland, Washington (November 1 , 1976). 
References (continued)

3. J. R. Raymond, D. A. Myers, J. J. Fox, V. L. McGhan, P. M. Schrotke, Environmental Monitoring Report on Radiological Status of the Ground Water Beneath the Hanford Site, January-December 1974, BNWL-1970, Battelle, Pacific Northwest Laboratories, Richland, Washington (March 1976).

4. R. K. Ledgerwood, C. W. Myers, and R. W. Cross, Pasco Bas in Stratigraphic Nomenclature, RHO-BWI-LD-1, Rockwell Hanford Operations, Richland, Washington (May 4, 1978).

5. S. N. Davis and R. J. M. DeWiest, Hydrogeology, Wiley and Sons, New York, New York (1966).

6. A. M. LaSala, Jr., and G. C. Doty, "Preliminary Evaluation of Hydrologic Factors Related to Radioactive Waste Storage in Basaltic Rocks at the Hanford Reservation, Washington," U. S. Geological Survey OpenFile Report, 1971.

7. J. A. Lier, The Solubility of Quartz, Utrecht, Kemink en Zoon, 54 pp. (1959).

8. G. W. Morey, R. 0. Fournier, and J. J. Rowe, "The Solubility of Quartz in Water in the Temperature Interval from 25 to $300^{\circ} \mathrm{C}$, " Geochim. et Cosmochin, Acta; 26, pp. 1029-1043.

9. R. A. Deju, Regional Hydrology Fundamentals, Gordon and Breach Science Publications, New York, New York (1971).

10. F. J. Pearson, Jr., and B. B. Hanshaw, "Sources of Dissolved Carbonate Species in Groundwater and Their Effects on Carbon-14 Dating, " in Symposium on Use of Isotopes in Hydrology, International Atomic Energy Agency, Vienna, Austria, pp. 271-286 (1970).

\section{DISTRIBUTION}

$\frac{\begin{array}{c}\text { Number of } \\ \text { Copies }\end{array}}{2}$

3
PACIFIC NORTHWEST LABORATORY

J. R. Raymond

J. R. Serne

THE PENNSYLVANIA STATE UNIVERSITY

G. J. McCarthy 
Distribution (continued)

Number of

Copies

W. K. SUMMERS AND ASSOCIATES

2

U. S. DEPARTMENT OF ENERGY-HEADQUARTERS

M. W. Frei

D. L. Vieth

2.

U. S. DEPARTMENT OF ENERGY-RICHLAND OPERATIONS OFFICE

R. B. Goranson

D. J. Squires

1

U. S. GEOLOGICAL SURVEY

C. Collier

1

UNIVERSITY OF MINNESOTA

M. P. Hardy

WASHINGTON STATE DEPARTMENT OF ECOLOGY

P. Grimstad

50 ROCKWELL HANFORD OPERATIONS

R. C. Arnett

R. L. Biggerstaff

D. J. Brown

D. J. Cockeram

T. A. Curran

R. A. Deju (5)

H. B. Dietz

G. C. Evans

M. R. Fux

R. E. Gephart (3)

R. J. Gimera

R. Johnston

A. D. Krug

W. P. Kunkel

A. G. Law

R. K. Ledgerwood

J. T. Lillie

P. E. Long

C. W. Myers

S. M. Price

S. P. Reide1

M. J. Smith (3)

F. A. Spane

Basalt Waste Isolation Program Library (15)

Document Control (4) 